\title{
Interpreting Estonian mires: common perceptions and changing practices
}

\author{
PIRET PUNGAS-KOHV, RISTE KESKPAIK, MARKO KOHV, KALEVI KULL, TÕNU OJA AND \\ HANNES PALANG
}

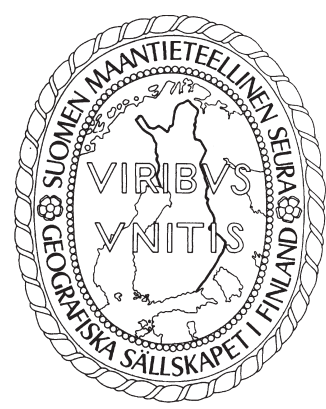

Pungas-Kohv, Piret, Riste Keskpaik, Marko Kohv, Kalevi Kull, Tõnu Oja \& Hannes Palang (2015). Interpreting Estonian mires: common perceptions and changing practices. Fennia 193: 2, 242-259. ISSN 1798-5617.

Over the centuries mires have been considered to be mostly useless, even dangerous places. Adopting a landscape semiotic perspective the article delineates the current common perceptions of Estonian mires based upon 767 questionnaires. Today the mire is commonly perceived as undisturbed wilderness offering possibilities for various recreational as well as traditional activities. The image of mires in popular consciousness is predominantly based on touristic experience of protected areas. The history of the most widespread practices in the mires over the 20th century reveals three general paradigmatic frames of reference: traditional where mire appears to be liminal; industrial where it is encultured; and ecological where mire is aestheticized. In its orientation towards aesthetic and emotional values the common perspective diverges from the landscape ecological definition. Tourism to non-protected, partly meliorated mires should be encouraged to give a more realistic perspective of the mires to nonprofessionals.

Keywords: mire, raised bogs, phenomenology, perception

Piret Pungas-Kohv \& Tõnu Oja, Department of Geography, University of Tartu, Vanemuise 46,50410.E-mail: piret.pungas@ut.ee, tonu.oja@ut.ee

Riste Keskpaik \& Kalevi Kull, Department of Semiotics, University of Tartu, Jakobi 2,51014.E-mail: riste.keskpaik@ut.ee,kalevi@ut.ee

Marko Kohv, Department of Geology, University of Tartu, Ravila 14a, 50411. Email: marko.kohv@ut.ee

Hannes Palang, Center for Landscape and Culture, Estonian Institute of Humanities, Tallinn University, Uus-Sadama 5, 10120.E-mail: hannes.palang@tlu.ee

\section{Introduction}

During the last half-century, mires, together with other wetlands, have gained considerable attention as very important providers of various ecosystem services such as greenhouse gas regulation, water supply and regime management, nutrient buffering during the last decades (Costanza et al. 1997; De Groot et al. 2006). However, as Giblett (1996) points out, the cultural meaning and importance of the mires have been rather marginal and negative for centuries as those areas are generally poorly suited for human settlements. He tries to deconstruct the negative meaning about the wetlands us- ing examples from the whole world. More detailed investigations are available for Iceland (Huijbens \& Pálsson 2009) and England (Van de Noort 2004).

The process and background of draining mires in Russia due to land shortages have been described by French (1964). Among other things he highlights the detrimental influence of mires on the health of people. "The wet lands were notoriously unhealthy for man and beast. In the northern provinces/.../ anthrax was endemic in swamp areas. In Poles'ye, ague, or malarial fever and elflock/.../ were widespread" (French 1964: 176177). Tanskanen (2011) discusses the historical background of mires, attitudes towards them and 
practices in them in Finland. Among negative attitudes she mentions the people's fear of mires as an environmental factor potentially conducive to night frosts that would increase the likelihood of the failure of agricultural crops during the brief vegetation period. Lehtinen (2000) describes the negative attitude of the Finnish people towards the mires up to the 1960s that saw them as "threatening landscapes of expanding mosses" that were considered as "challenging the basic identity construction and economic development of Finland" (Lehtinen 2000: 178).

In recent decades, next to ecological values, the general attitudes towards the mires have been shifting. This new shift can be clearly tracked because of the conspicuous distinctiveness of the mires that is attracting the attention of the rapidly growing tourism industry which is seeking places that offer new and different experiences. The mainly negative connotations of mires as predominantly creepy and worthless places have in recent decades been positively replaced with those of valuable wilderness (Howarth 2001), a rich resource for (tourism) marketing in the globalizing world. In turn, the changes of cultural concepts and practices direct and sometimes initiate the future human actions in mires and therefore influence the size and ecological quality of those areas.

The perception of mires in the Estonian context has changed rather abruptly during the $20^{\text {th }}$ century, together with the accompanying modifications of institutional practices (Pungas \& Võsu 2012). Archaeological sites, that date back to 8900 BC in Estonia, are often found close to today's mires (Kriiska 2004), which at that time rather used to be lakes and were used as water roads, indicating ancient ambiguous relations to the wetlands/ water bodies (Pungas \& Võsu 2012). Nowadays peat lands, that incorporate both natural mires and drained mires, cover over 1/5 of the Estonian territory (Paal \& Leibak 2011).

\section{Definition of mires in the landscape ecological sense}

Mires are part of the broadly defined 'wetlands', habitats with the common quality of being excessively water rich. The definition by the international Ramsar convention (www.ramsar.org) covers a quite large number of very different habitats like shallow $(<6 \mathrm{~m})$ lakes and seas, peat lands, frequently flooded meadows, etc. Wetlands are con- sidered as one of the most valuable ecosystems of the entire Earth (Costanza et al. 1997). Natural mires are important providers of various ecosystem services (Kimmel et al. 2010). The term 'mire' in the ecological sense is usually defined via peat - a mire is an area where peat thickness exceeds $30 \mathrm{~cm}$ and peat accumulation continues at present (Paal \& Leibak 2011). Approximately 22\% of the Estonian territory is covered with peat (Valk 1988) but most (three quarters) of it is artificially drained and therefore the accumulation of peat has currently ceased. The term "peat land" is used to describe such drained areas together with active mires (Joosten \& Clark 2002). Therefore only ca. $1 / 4$ of the peat land in Estonia can still be defined as mires with ongoing peat accumulation (Paal \& Leibak 2011).

\section{The cultural perception of mires}

The landscape ecological definition of mires is fairly recent compared to the age of the human settlement in Estonia. People's long-term relations with mires are reflected in language: the word soo (mire) was assumedly used already in the Stone Age 6000-7000 years ago (Ilomets et al. 2007).

For instance, a Thesaurus of the Estonian language published in 1958 (Saareste 1958) reflects a rich vocabulary relating to bogs and mires (nearly 300 replies to searches in the web database), the majority of which has vanished from actual use by today. In popular usage soo (mire) and raba (bog) are used interchangeably or often as a pair of words in the plural (sood-rabad) to denote all kinds of wet areas unsuitable for cultivation (Masing 1968). However, in everyday conversations those terms have a wider meaning than that of a scientific description - for example, drained peat lands or any wet, soft mineral soils are still described as soo. The narrowing of the term's content in popular usage occurs as well - people often do not describe wet forests as 500 although those habitats are mires according to the landscape ecological definition.

\section{Objectives and aims of the article}

Today the fate of natural mires in Estonia is determined by mainly two different institutional aims: their industrial use and/or conservation. Both viewpoints rely on technical definitions of what mire is. These institutional definitions as well as the following management decisions are not necessarily compatible with people's and local communities' uses and perceptions of the mire (see for ex- 
ample Lehtinen 2010, 2011). We were interested in this tension between the technical landscapeecological definition and the perception of the mire in popular consciousness; to what extent are they compatible, and to what extent not. What significant aspects of the mire for people are disregarded in institutionally driven decision-making? A better understanding of local perspectives should enhance the communication of institutional aims (e.g. conservationist) to the public if institutions want acceptance of their decisions from the public. It would also improve the quality of management decisions regarding the future of mires taking into account the diversified uses and meanings that the landscape enables for stakeholders.

The aims of the present study are: a) to identify the current common perception of mires in Estonia; b) to analyze the common perception of mires and compare it with the landscape ecological perspective; and c) to suggest ways to bring the aspects of mires that are usually missing from common perception (such as the extent of managed mires) to public awareness.

\section{Theoretical framework}

The theoretical framework of the study is based on two fundamental questions: how to connect the landscape-ecological definition of the mire with landscape semiotics and what discourse within the landscape semiotics is the most useful in our case? From the latter, we may say that the possible contribution of semiotics to landscape studies is not limited to representationalist accounts departing from the structuralist semiology of the Saussurean tradition such as for example Cosgrove (2003). Rather, the broader framework of general semiotics pertaining to the processes of communication and meaning-making constitutes a capable theoretical-methodological basis proceeding from which landscape can be defined as an interactive dynamic process, integrating its material dimensions with symbolic ones.

Providing an overview of the relations between landscape semiotic studies and disciplinary semiotics, Lindström et al. (2013: 97-98) conclude that although "there has been little explicit usage of semiotic terminology in landscape studies [...] a wealth of inherently, albeit implicitly, semiotic scholarship has been produced on topics such as landscape representations and preferences, the manifestation of power relations and the embodi- ment of social structures and memory in landscapes. There are many works that could potentially belong to landscape semiotics but which do not identify themselves as such".

We will use theoretical help from ecosemiotics to bridge the gap between landscape ecology and landscape semiotics. The term 'ecosemiotics', denoting semiotic interrelations between organisms and their environment, has been in use since 1996 (see Kull 1998; Nöth 1998). The central focus of ecosemiotics is concerned with the impact of the conceptual structure of humans' knowledge of the environment upon the environment itself, that is, how the linguistic and cognitive aspects of the human Umwelt influence human actions towards the surrounding nature.

The trans-disciplinary field of humanist landscape studies and ecosemiotics (Nöth \& Kull 2001; Maran \& Kull 2014) intersect befittingly in the works of the anthropologist Tim Ingold. Ingold's contribution to both landscape studies and the semiotic studies of the environment lies in the cognitive manner in which he demonstrates how meaningfulness is inherent and arises from being embodied in the material world - in the processes that he, drawing upon Heidegger (1971), calls $d$ welling (Ingold 2000). In the dwelling perspective organism as an embodied center of agency (human and non-human) is in a mutually interactive relationship with its material surroundings: the organism is constantly changing the environment but at the same time needs to adapt to the same changing environment.

Dwelling, however, is necessarily a semiotic entanglement, since a living being is not interacting directly with its 'true' environmental conditions, but towards a (species-specific) representation of the environment rendered to the organism by its ensemble of various sense organs. The theoretical basis for this approach has been provided by Jakob von Uexküll (1982 [1940], 1992 [1934]) in his Umwelt-theory.

In this context the term 'landscape' is used to refer specifically to the shape that the physical surroundings have taken and are taking in the course of dwelling activities (tasks) that are being carried out there (see Ingold 2000: 193). Meaning is thus not something inscribed upon the "inert matter of nature" from the 'outside', by social codes and contexts external to it but is "immanent in people's pragmatic engagement with the world" (Ingold 2000: 154, 2011: 333). Discovery of the meaning in the human landscape, he argues, has to begin 
from the recognition of its temporality, from identifying the past interactions and processes that have contributed to its present form.

The dwelling perspective on landscape may help to bridge the gap between the landscape ecology approach that implicitly gives precedence to the (natural) environment surpassing the beings in (and their perceptions of) it and the humanistic constructivist perspectives that give primacy to cultural representations. We hold that the meaning of landscape is constructed by people constantly and non-linearly evolving a multilayer perception that combines materialistic, symbolic and behavioral aspects (see Keisteri 1990).

\section{Methods}

Our methodological approach in this article derives from a phenomenological understanding in wider sense. As an interdisciplinary work, it draws upon a perspective on landscape that is more general than the phenomenological one, and still mainly indebted to Ingold's thought. We take practical engagement with the mires to be the basis for their meaningfulness to people and follow how the socio-economic changes in the practical relationship have affected the physical form of Estonian mires. Those practices are intertwined with cultural perception, people's fundamental conception of the world, of the natural environment and themselves in relation to it. We apply both quantitative and qualitative methods in data compilation and analysis.

\section{Questionnaire}

The poll was carried out in 2006-2007; in total 1,000 questionnaires (in Estonian) were distributed. The distribution of the questionnaires between the counties followed the general population distribution. Public libraries were chosen as focal points for questionnaire distribution, chosen because of the relatively wide coverage among the population subgroups, as convenient places to fill in questionnaires and also as one of the most economical choices available.

The questionnaire consisted of 23 questions and it took approximately 20 minutes to complete. $43(90 \%)$ libraries returned 592 filled questionnaires to the researchers. As the numbers of filled-out questionnaires from the capital Tallinn were low, three schools in Tallinn were asked to distribute questionnaires (86) to students in the winter 2006, and additional 89 questionnaires were handed out to Tallinn residents on the Tallinn-Tartu train in 2007. The total number of the filled questionnaires is 767 .

The respondents were divided into seven age groups (Fig. 1).

Young people (15-29) were more responsive compared to their share in the population. Children (0-14) are the most underrepresented age group - the youngest (0-7) usually do not visit libraries on their own. The share of responses from female respondents $(64.9 \%)$ is slightly higher than that in the population (53.4\%).

The share of responses from 15 counties plus Tallinn is presented in Figure 2 as compared to the share of the Estonian-speaking population in the particular region. Tallinn and Harju County are relatively underrepresented, but as the total number of respondents from both is high, there is no reason to believe that qualitative answers are missing.

A relatively high return of responses came from Viljandi - the county where Soomaa Nature Park, one of the best known wetland areas in Estonia, is located.

Altogether the cohort of respondents corresponds reasonably well to the share of the respective groups in society and therefore the generalization of the findings is justified.

In order to check the possible variability of the answers, subsamples were formed from the full samples pertaining to each question (767 answers each), leaving out blocks of 50 answers that differ in each subsample. The subsamples and the mean values of the answers to the full sample were compared. The differences between the subsamples are negligible; the coefficients of variation

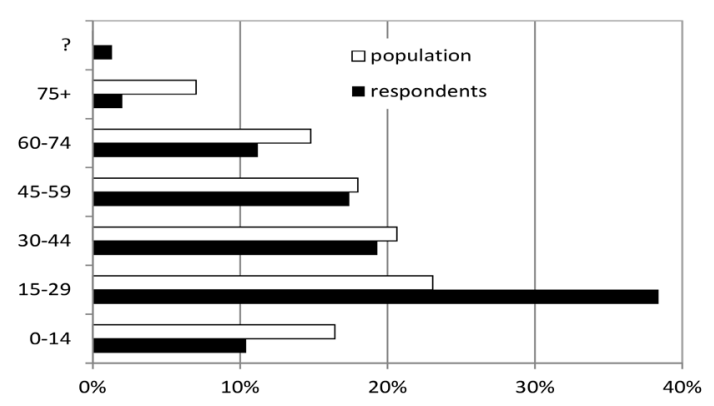

Fig. 1. The age distribution of the respondents and share in Estonian speaking population. 


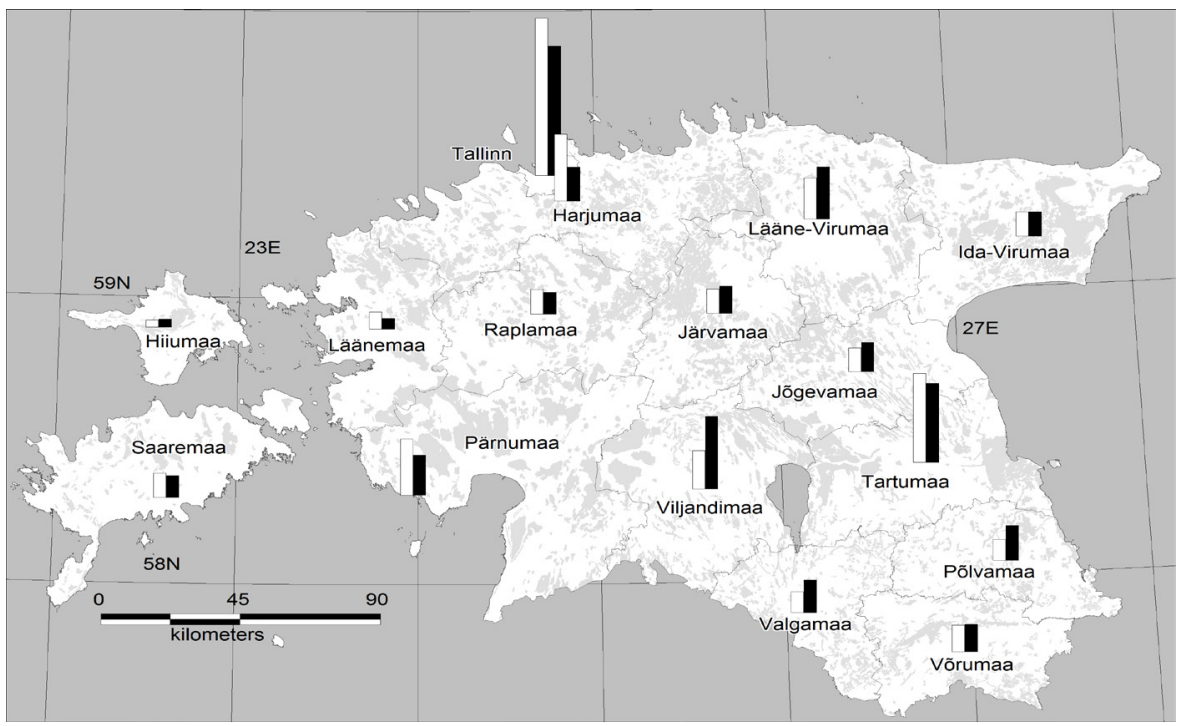

Fig. 2. Division of the respondents county wise on the background of mires (light grey). for the eight most popular keywords are $1-2 \%$. Also, a similar test was carried out comparing 19 subsamples of different sizes from 618 to 767 each, formed by leaving out responses from one region (county or city) in each subsample. The variability between the subsamples is very low also here (CV percentage for eight most popular keywords are $1-3 \%)$. The differences between male and female respondents are a bit higher (CV percentage 5-9\%) than regional differences but the principal sequence of the keyword frequency is the same. Similar tests were carried out also for the responses about visiting frequency and purposes and the variability between the subsamples remains low. Therefore we can conclude that the findings are representative to the Estonian-speaking population.

In this article, we refer to the answers to four questions presented in the questionnaire that describe the person's practical and emotional relations with mires. The questions were: 1 ) how often do you visit mires; 2) when do you visit mires; 3) why do you visit mires; and 4) what would be the five main keywords you would use to describe a mire.

Answers to those questions were open for respondents. Any additional clues or selective answers were not presented.

Content analysis was used to process the answers (Flick 1998). Classification of the answers was done by two experts to ensure consistency.
Word counts were weighed according to the number of the keywords in the answer (for example: one keyword weighed 0.33 if the respondent provided three keywords; 0.2 in case of five keywords etc.). The weights of the classes were finally summarized. The classes that remained under the 1\% threshold after grouping are not included in the current study or have been mentioned only if qualitatively significant. The responses were content analyzed using SPSS 8.0 and Excel.

The results of the content analysis are interpreted within the context of changing mire practices. The overview of historically most common practices was compiled on the basis of an extensive review of popular scientific literature.

\section{Literature as a source for finding descriptions of the most common mire practices through time}

Descriptions of the most common mire practices come from popular science literature published in Estonia since the 1920s including textbooks, travel guides, project reports, journals, etc.; fiction was excluded (Tüür \& Maran 2005). It was assumed that this kind of literature has a more considerable impact on people's personal meaning of mires as some of it is mandatory literature (especially school textbooks). 
Mire practices were defined as behaviors and practices that led to personal contacts with mires.

\section{Changing practices $-\mathbf{a}$ historical overview}

Traditionally mires were feared and avoided; farmers had no business there, except when going hunting or picking berries. In traditional lore, the mire is first and foremost reflected as a dangerous place populated by evil-minded creatures and supernatural forces. According to the Estonian Folklore Archives the following creatures and curious phenomena can be found in the mire: the nixes, will-o'-the-wisps, skeletons, souls of the dead, revenants, snake kings, spooks. "A peat land landscape instilled a feeling of insecurity. Moving on a soft peat land surface was dangerous for both livestock and humans. Drowning in bog pools or being swallowed up by a quagmire was long remembered and retold" (Hiiemäe 1988: 221). The most characteristic tales about mires to be found in the Estonian Folklore Archives concern the creation of mires, mythic creatures and folktale-style measuring of the depth of bog pools - the latter were, of course, bottomless. The property of peat to conserve wood or casual items lost in the mires supported popular beliefs about hidden treasures.

\section{Refuges}

Difficult to cross even for those well acquainted with the local conditions, mires have provided shelter for those escaping from war, oppression or diseases since ancient times.

By the beginning of the $13^{\text {th }}$ century supposedly only $6-9 \%$ of population could find shelter in ancient strongholds (some of which were located on bog islands) in case of threat, so the majority of the population had to find alternative refuges closer to home (Tõnisson 1972). Mires were well-suited for that purpose. In Estonia over 80 wooden track ways laid in bogs and marshes are known based on archaeological investigations as well as the oral tradition (Lavi 1998).

From the $16^{\text {th }}-18^{\text {th }}$ centuries the wooden track ways were of remarkable military importance. The Stockholm State Archive houses a map ordered by the Swedish authorities between 1616 and 1629 representing a number of these track ways in the territories of Estonia and Livonia (Einer 1980; Lavi 1998).
Wars and oppressions have been common throughout Estonian history, so the need for refuges has persisted. In times of serfdom, peasants sometimes escaped to the mires to avoid punishment by hostile landlords; in the $19^{\text {th }}$ century young men escaped from the conscription to the Russian military service that lasted for 25 years. During World War II and the post-war period some ancient asylums in bog islands and forests were adopted by anti-communist guerrillas.

\section{Winter roads}

Up until as late as the beginning of the $20^{\text {th }}$ century Estonia's abundant marshy areas presented a great obstacle to travel and transport. Roads had to go round them and in warm season many back-country corners were nearly unapproachable. There was no actual need to complete or maintain long-distance roads for some time as sledge caravans usually travelled in winter along the temporary network of winter roads (Einer 1980). The long northern winter enabled to create an alternative and shorter network of winter roads that did not coincide with that of summer traffic. Only in primeval forests did the summer and winter tracks coincide (see Läänelaid \& Loosalu 1978). Mires are naturally open areas, therefore generally suitable for fast transport and the only obstacle, soft ground, is naturally eliminated when water freezes. Mires are also usually very well connected to the river network that served as a naturally forming road network as well (for further details, see Joandi 1990; Kask 1990).

Beside their importance for foreign trade winter roads were vital for the local livelihood, enabling to transport timber and firewood out from the forests, or bring home hay from marshy grasslands (Einer 1988). All that has remained of former winter roads over mires are trails perceivable from aerial photographs, tavern ruins and episodic data from historical archives. In places they have been used for transporting timber or renewed for the purposes of tourism.

\section{Berry picking}

Estonian mires are naturally abundant in wild berries, especially cranberries (Vaccinium oxycoccus), bilberries (Vaccinium myrtillus), bog bilberries (Vaccinium uliginosum), cloudberries (Rubus chamaemorus) and lingonberries (Vaccinium vitisidaea) grow on the fringes or on bog islands. Cloudberries are considered delicacy as they occur less 
often. Before the passing of the Land Act in 1919 Estonian peasants had limited rights to collect wild berries from the land that belonged to the Baltic German nobility. Usually, they had to share the harvest with the landlords. Nevertheless people went to pick berries, often in secrecy, to diversify their diet.

During the first period of independence (19181940) berry picking and preserving for individual use was relatively modest, even though the export of wild berries was quite significant in the 1930s and activities related to consumption provided additional income for rural inhabitants.

After World War II the deficiency economy and the lack of officially distributed goods forced people both from rural as well as urban regions to turn back to traditional gathering and to conserve wild berries for sustenance. Under the Soviet rule, the land was nationalized in 1945 and collective forest enterprises were formed that were also supposed to manage the by-products of forestry. "Since the export of wild berries and mushrooms provided the Soviet Union with highly valued foreign currency, collecting norms were imposed upon the states. /-/ Gathering peaked in the 1960s and 1970s" (Paal 2011: 70). Gathering at that time was so intensive that to prevent half-ripened berries from being picked prematurely official dates for picking had to be established (Paal 2011). As the living standards gradually improved but the prices for state purchase remained low, the interest in gathering wild berries was reduced. The increasing use of cultivated garden berries also contributed to this. The so called "berry-economy" collapsed together with the collapse of the Soviet Union as the old purchase system broke down and no new one had been established. Limits to personal consumption were set by the deficiency of sugar before the 1990s and later by high sugar prices. In the middle of the 1990s, the purchase of wild berries started to gather new momentum. Wild berries have added variety to the Estonians' diet throughout times, but the intensity and meaning of berry picking has been varying together with changes in the socio-economic conditions (see Bardone \& Pungas-Kohv 2015).

\section{Melioration and peat-cutting}

While traditional practices had hardly any remarkable or long-term effects on mires, economic interests and the accompanying melioration works, especially over the last century, have totally transformed the whole mire landscape in Es- tonia. The draining of mires for agricultural and peat mining purposes started already in the $17^{\text {th }}$ century. Peat is an important natural resource in Estonia and holds the third position as fuel after oil shale and wood. Peat-mining increased considerably at the end of the $18^{\text {th }}$ century when it was adopted as fuel in manor distilleries, but it was used also for heating farmhouses and as litter for cattle (Paal \& Leibak 2011).

By the $19^{\text {th }}$ century the draining and burning of peat fields for agricultural ends was widespread. In 1908, the Baltic Mire Improvement Society was founded in Tartu in order to provide scientific assistance to farmers and manor owners concerning drainage methods and systems. Human labor was gradually replaced by machines and the extent of the drainage systems increased rapidly in the $20^{\text {th }}$ century, especially after World War II. Under the Soviet regime melioration for agricultural and forestry purposes peaked in the 1970s. According to the analysis of different data, by the 1990s around $70 \%$ of Estonian peat lands had been drained or affected by draining to the extent that further peat forming had stopped (Paal \& Leibak 2011).

\section{Conservation}

The greatest threat to mires has been and still is melioration, but nowadays also the increasing demand for horticultural peat has to be taken into consideration. Estonia currently holds from third to fourth position in the world (Paal \& Leibak 2011) as exporter of horticultural peat. Since the 1970s the significance of the ecological role of mires has increasingly been acknowledged, as well as the need to defend them from further economic pressure.

The protection of mires in Estonia actually arose from the need to protect eagles (Aquila chrysaetos), who prefer to nest in the mires which form extended enough natural areas: a reservation was founded in Ratva bog in 1938. In 1957, several large nature reserves containing wetlands were formed, including Matsalu (floodplain and coastal grasslands), Nigula (bog) and Viidumäe (spring fens) as well as a number of asylums of local importance.

In 1968 a heated discussion (Masing 1968) started between scientists and ameliorators in the popular magazine Eesti Loodus (Estonian Nature), in the course of which the ecological value of peat-lands was brought into public attention. This process has later been referred to as "the war about 
mires". As a result, 30 new mire reserves were established in 1981 (Valk 1988).

After regaining independence in 1991, Estonia has joined a number of international conventions regulating nature conservation, the preservation of biodiversity and quality of environment. In 1994 two conservation areas rich in mires and marshes were created - Soomaa National Park and AlamPedja nature reserve. In 2012, $72.5 \%$ of the remaining natural mires in Estonia were under protection (Kohv \& Salm 2012). As a new initiative, some small-scale wetland restoration projects have been proposed during the last decade. First wetland restoration projects are currently evolving in Estonia with the help of the European Union funds.

\section{Tourism and nature education}

Specific tourist services as well as the concept of mire tourism have appeared mostly in the last decade (see for example Tooman \& Ruukel 2012); however, the recreational value of mires has been recognized for much longer. The 1960s and 1970 s witnessed the initiative of creating nature education trails, encouraging people to learn about and to experience directly local communities (Eilart 1986). The existence of infrastructure is especially important in case of mires as without boardwalks mires would be accessible only to a few adventurous individuals. In 2005, Paas counted the total of about 60 nature trails (about $75 \mathrm{~km}$ ) consisting wholly or partly of wooden boardwalks in Estonia, the majority of which had been laid in the last decade. In Estonia boardwalks have mostly been built into mires, or to wet spots on other nature trails (Paas 2005). Boardwalks are often accompanied by viewing towers (32 in number), adding a different dimension to the mire experience (Printsmann et al. 2004). According to the State Forest Management Centre (2014), who is the manager of all nature trails since August 2010, the number of visitors to the mires was around 76,000 during the high season between 2009 and 2011. According to one wilderness tourism entrepreneur there are currently 15 enterprises offering snow shoeing tours in Estonia, introducing mire landscape to around 5,000 to 10,000 people a year (Rähni 2012).

Since the 1990s wilderness tourism has been gaining popularity globally. Extreme environments not suited for (human) habitation that have therefore escaped (visible) human impact and (assumably) retained their naturalness are increasingly opened/adopted for tourist experience/possibili- ties/ends. This is often interpreted also as a possibility to protect them from other, more intense economic pressures - as in the case of ecotourism.

\section{Results of the questionnaire}

\section{Frequency of visits}

According to the replies of the questionnaire, most of the respondents visit mires a few times a year (38.7\%). 18\% go to mires less than once every two years and an almost equal number (17.5\%) visit mires once a year (Fig. 3). Generalizing the answers to the entire Estonian-speaking population (around $0.92 \%$ ) says that around 500,000 people visit mires annually. Obviously, the vast majority of the respondents answered the questionnaires for the very reason that they have had contact with mires. Only $8.6 \%$ of the respondents stated that they have not visited mires. Therefore the following results can be generalized to the people who have visited mires at least once in a lifetime.

\section{Seasonality of visits}

Autumn and summer are almost equally popular seasons for visiting mires: $37 \%$ and $29.7 \%$ of the answers correspondingly (Fig. 4). This is congruent with the fact that picking berries appears as the main purpose of visiting the mire (Fig. 5). The possibility rediscovered by (mire) tourism entrepreneurs to use snowshoes for creating eventful hikes to mire also in wintertime (2.2\% of the answers) helps even out the seasonality of visits. Since the rapid disappearance of the importance of winter roads in the last century, the mires have been visited primarily in the warm season.

The number of respondents going to the mire in spring $(12.1 \%$ of the answers) or around the year $(11.3 \%)$ may also refer to the increase in the recreational purposes of visiting: in addition to springtime hiking and study trips, for example also bird watching and nature photography.

\section{Purpose of visits}

The greatest number of respondents (42.1\%) goes to the mire to pick berries (cloudberries, cranberries), sometimes also mushrooms or herbs. Recreation, most notably in the form of walking, hiking and (study) trips is a common purpose too (36.6\%). 


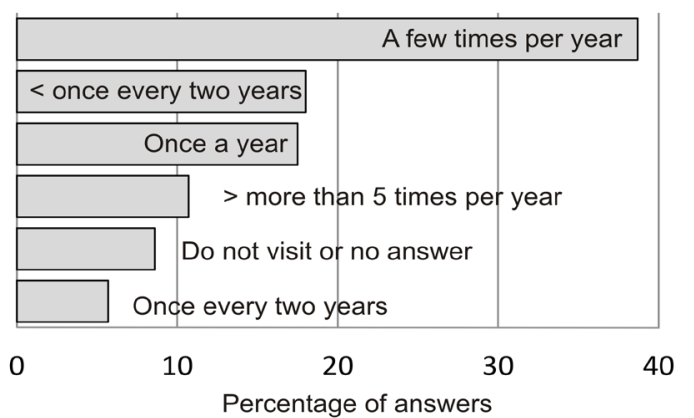

Fig. 3. Frequency of visiting mires.

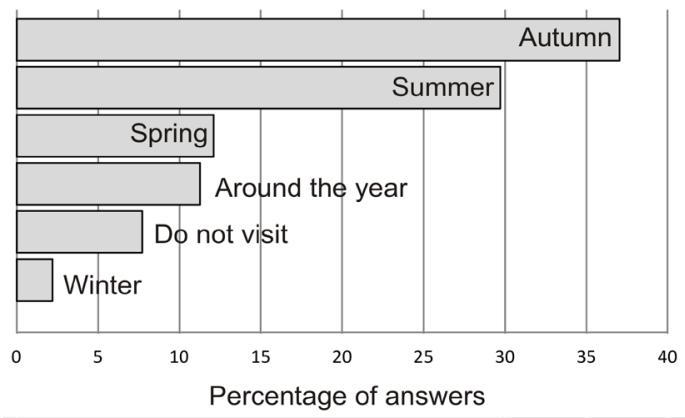

Fig. 4. Seasonality of visits.

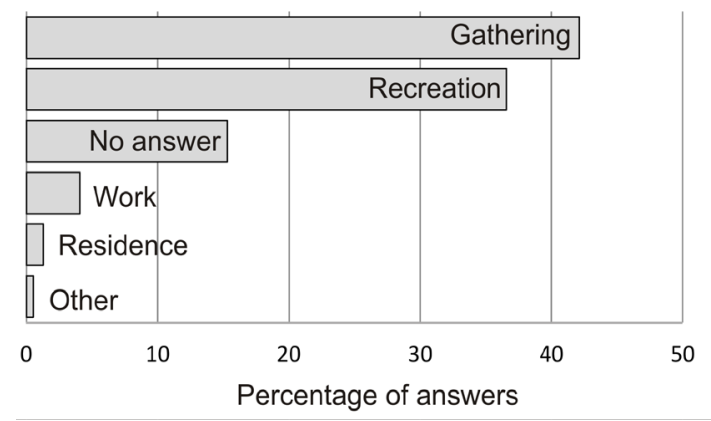

Fig. 5. Purpose of visits.

Among recreational activities also skiing, canoeing, orienteering, photography, swimming and sunbathing, hunting and fishing were mentioned. $4.1 \%$ report to have been working professionally or temporarily in the mires, their jobs being related to peat mining, foresting, melioration, nature protection and tour guiding. The category of professional work also includes research that has been done in the mires. Temporary or voluntary work most often consists in the building of walkways, clean-up, or, more traditionally, making hay or firewood. $1.3 \%$ of respondents marked the mire as a residence.

\section{Five keywords}

The most popular group of keywords (20.0\%) relates to water, wet pools and the insecurity of walking on soft and turfy ground (Fig. 6). Water, the wetness of mires as their most distinctive feature arouses contradictory feelings. The rather frequent mention of the fear of sinking, drowning or just getting caught in the gurgling slough reflects the archetypal fear of liminal or borderline phenomena, which runs deeper than just practical considerations - in traditional lore the mire has been described as "land, but it is not walkable, [there is] water, but not navigable" (well-known proverb). Although hollows (älves) are actually more dangerous, in common consciousness the danger of the mires is related to wet pools (open water bodies). Also the unpleasant sensations of wet feet or squashy boots have been mentioned, unless one is wearing rubber boots suited for the purpose. On the more positive side of the water in the mires fresh water reservoirs and the pleasure of swimming in wet pools have been described. This is sometimes encouraged but sometimes altogether prohibited by the information tables.

The distinctive appearance of mires vastly results from their characteristic vegetation. $15.4 \%$ of the keywords can be related to plants, or also, more generally to the mire as an exceptional ecological community. Characteristic plants like sundew (Drosera), heather (Calluna), mosses (Sphagnum) and lichens, bog pines, dwarf birches, sedges have been mentioned as well as some general features of plant life in the mires - thin and poor vegetation, lack of nutrients, lack of diversity. A realistic danger, also referred to by some respondents, is losing orientation in the mire as the (visually) unvarying mire landscape often lacks in distinguishable landmarks.

Keywords related to the visual beauty and other sensory perceptions of the mires constitute the third important group (12.9\%). Although vision is still the dominant sense, there are references to other senses as well. The picturesque and spacious views, autumn colors, sunrise and sunset are accompanied by the distinctive smell (of Labrador tea) (Ledum palustre) and particular sounds like the whooping of cranes (Grus grus). 
$11.5 \%$ of the keywords address the emotions and states of mind that arise in the mire. The vast open perspective, peace and quiet, lack of timemotion contributes to the mystical feelings of being in contact with something ancient, reverence, renewal and deep unity with nature. Some respondents express joy and emotional pleasure arising from the natural beauty and exoticism. Others experience sadness and forsakenness, the insignificance of human beings.

$11.2 \%$ of the keywords relate to gathering as the most common activity in the mires.

Similar and almost equally important for the respondents is the untouched wilderness of the mires $(10.4 \%)$. Clean air, fresh water, lack of human presence or (visible human) impact contributes to an aura of pristine nature and the idea of an ecologically balanced environment.

Encounters with bird and animal life are memorable and create excitement $5.9 \%$ of the keywords). Birds' migration, eagles' nests, grouse play, cranes, frogs, elks and animal burrows belong to the exciting side. Annoying bugs, horseflies and snakes on the other hand are rather repellent. It could be the case that due to thin vegetation birds and animals are easier to notice in the mire, but also the information tables or bird watching towers often direct attention to the signs of wildlife.

$5.2 \%$ of the keywords directly refer to recreational activities (physical activity and endurance, different sports, being healthy, a chance to be alone and to relax) and tourism (trips and hiking). The related infrastructure - wooden walkways, information boards, observation towers, forest huts - as well as good company and friends have been mentioned as well.

$2.1 \%$ mentioned peat or peat industry; fear is reflected by different keywords altogether by $1.8 \%$ of the respondents; $1.3 \%$ did not give any response.

The categories of keywords below $1 \%$ include research and education $(0.4 \%)$, nature protection and environmentalism $(0.3 \%)$, weather and seasons $(0.5 \%)$ and the inaccessibility of mires $(0.4 \%)$ and other.

\section{Discussion}

The results of the questionnaire demonstrate that respondents, generally people who have had contact with mires at least once in their lifetime, tend to visit mires relatively often - more than $50 \%$ of the respondents go there at least once a year. It indicates that most people have positive personal experience of being in the mire environment in addition to the information about them from media or school curriculum. Next to gathering, with its practical reasons, other objectives for going to the mire today are almost invariably touristic, recreational or emotional. Among ordinary visitors, the mire is rarely associated with work or industries. Scientific/ecological references to mires are of minor importance.

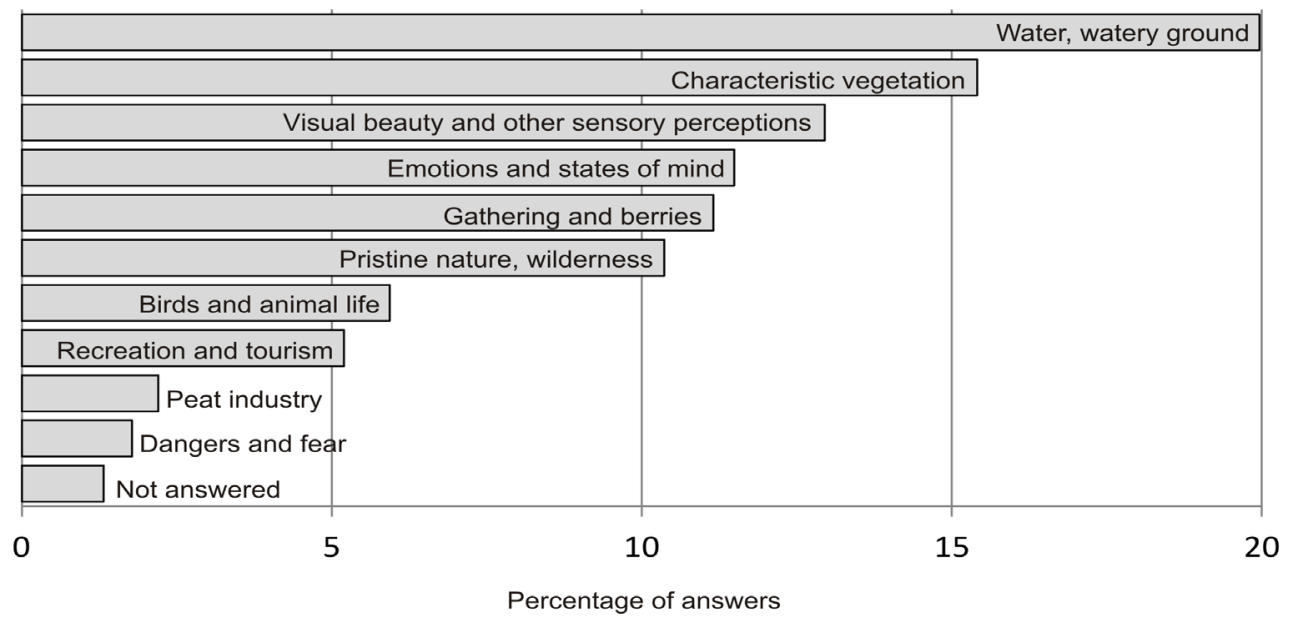

Fig. 6. Frequency of the five keywords associated with mire. 
Assumedly, the shift in practice and perspective has also brought about a shift in the seasonal distribution of the visits. Traditionally, mires were made most use of in wintertime when the land was frozen. Generally open wetlands were used as winter roads, thus invigorating communication and commerce. Today, only a rare hunter or hiker could be found wandering in the mire in winter as the function of winter roads is long gone.

Abundance of the summer and spring visits to the mire is a new phenomenon as traditionally it has been the time of the fewest visits. This increase is clearly related to nature tourism and recreation - activities almost unknown to general public before the middle of the $20^{\text {th }}$ century (Kimmel et al. 2010; Reimann et al. 2011; Tooman \& Ruukel 2012). Earlier this period of the year was 'filled' with excessive farm work and there was no practical reason to go to the mires as those areas were unsuitable for the common spring-summer economic activities.

Late summer and autumn has consistently been the most common time for visiting mires as berries and other gifts of nature ripen during that time. However, berries were traditionally harvested by the socially marginal groups, the children and the elderly, as the adult population was occupied with urgent harvest labors. The times at which the berries ripen are coinciding with periods of the most important traditional summer and autumn farm labors: haymaking time=bilberry, cloudberries; oats=lingonberries; rye $=$ bog bilberries; potatoes $=$ cranberries (see Bardone \& Pungas-Kohv 2015).

Berry picking was the most often mentioned singular activity that drives people to the mires even nowadays. In data analysis, we labelled the category 'gathering' as herbs and mushrooms were also mentioned on some occasions. Gathering appears to have been one of the main reasons for visiting mires throughout the centuries. The context and motives for gathering have varied over time (see for example Bardone \& Pungas-Kohv 2015), but the physical form of the practice has not changed much. According to Ingold (2000), meaningful and sustainable relations to the natural environment are above all to be found in the task-oriented bodily engagement with one's natural surroundings. We suggest that berry picking nowadays is a rare practice which helps to sustain or recreate a practical and immediate engagement with the natural environment characterized by Ingold as the dwelling perspective (Ingold 2000; Ingold \& Kurttila 2000). The following aspects help to explicate this point:
1. Berry picking in the mires requires remarkable amount of knowledge and skill. Not only has one to know when and where to go to find berries, but also various other practical details regarding what to wear or carry and how to find one's way. This knowledge, however, is not usually pronounced, save formalized, but is normally obtained through first-hand experience in the course of the activity itself - a process that Ingold (2000) has termed enskilment in opposition to discursive learning characteristic of the modern perspective. The practice is often picked up in childhood going to gathering trips with family or friends, or - and much more rarely - during institutional outings (that were common in the Soviet period). Thus, it supports intergenerational ties as well as ties with the traditional locality in some cases.

2. Berry picking is a corporeal, multisensory experience, much more so than leisurely walking or hiking. The experience includes the feel and taste of berries as well as getting wet feet, aching backs, bug bites and stained fingers. Berrypickers are dexterously in touch with the practical taskscape rather than oriented at the visual consumption of sights. Corporeality is inseparable from the embodied skill that gathering entails. Berry pickers normally find their own way around depending on the pre-established infrastructure only occasionally when it befits their aims, although nowadays GPS can help to find the way home. Similarly to traditional hunters the movement of the present-day gatherers is hardly linear but discontinuous "following the harvest" and involving the regular attunement of attention to their surroundings.

3. Berry-picking relies on and (re)creates locality/ landscape insiderness through wider cultural memory. Because of the manor system, until the mid-19th century most of the peasants were not landowners. Thus the habit of berry picking in Estonia has not remarkably depended on personal land ownership, but rather on the familiarity with ones' surroundings, and the attitude of the landlord. Even if personal ties to particular (ancestral) places have become cut by now, this has not much affected the popularity of gathering permitted by Everyman's right. Places of abundant yield are remembered and revisited. Information about them is distributed selectively, keeping it secret from the 'outsiders'. In the dwelling perspective the meaning of landscape is intertwined with temporality, en- 
compassing past/memory as well as anticipation and care for the future.

Apart from gathering, the most common activities in the mires are walking, hiking and excursions - recreational practices. Historically, "walking was understood to enable deeper and closer appreciation of natural scenery, and, as a physical, visual, and educational activity, it was seen as a way of bettering oneself, of becoming a physically and morally healthier person" (Wylie 2007: 129). Such pastimes (in nature) became generally popular together with the advancement of modernization, technological progress and urbanization whereby more and more people stopped working in the fields or woods and lost the immediate practical contact with the natural environment.

Recreational visitors can choose the time and place of visits more freely, their visits tend to understandably concentrate on the least 'stressful' places and times: such as sunny, calm days and easily accessible and physically undemanding routes. At first, some places, such as riversides were chosen or preferred because they naturally had those qualities, but active alteration, building special routes with bridges, stairs etc. quickly became a norm as the number of recreational visits increased. Active alteration also opens landscapes that were formerly considered as unsuitable for mass recreation such as mires that are naturally very demanding to cross.

Today, walking in the mire in Estonia is normally facilitated by specific infrastructure - wooden boardwalks together with viewing towers and information boards. The role of this infrastructure is ambiguous since on the one hand it renders the impassable landscapes accessible to the public, yet on the other hand, it effectively shapes and controls the experience. Macnaghten and Urry (1998) argue that routing constitutes one of the means by which visitors to natural areas are subjected to control and surveillance. Moreover, viewing towers and information boards that present information and guide visitors' attention and expectations confine tourists to specific sites/ sights, and orient their senses mostly towards visual experience. As Franklin (2003) remarks, the other side of this process is the obscuring, bracketing off and 'protection' of other sites/experiences.

Active alteration of landscapes for recreational purposes tends to cut off perception(s) achieved through the tactile and other more immediate senses, and enhance input from remote senses like visual perception. Macnaghten and Urry (1998: 113) argue that "this increasing hegemony of vision in European societies /-/ produced a transformation of nature as it was turned into spectacle". The perception that are considered 'unpleasant' like the sense of sinking in mires can be nullified via active alteration of the landscape - building non-slippery boardwalks - or weakened by the alteration of the visitor - the usage of snowshoes/bog shoes.

Active alteration of the landscape instead of the visitor leads to visiting natural areas like museums or reducing them to an aesthetically pleasing backdrop, essentially unimportant to the activity at hand. Nature is being stared at as an exhibit, with the idea of minimal mutual effect. The touristic forms of (dis)engagement with the wild thus appear to aim at creating an "authentic experience" without affecting nature or being affected by it at the same time. This is also pointed out by Franklin (2003: 240) who writes: "tourist organizations promise close contact but the structuring of the tour ritually and technically serves to create a distance between the tourist and the wild". After all, wilderness has always been, and has to remain, unaffected by definition.

More widespread bog shoe hiking would preserve an important perception related to mires ("soft ground") but usage of this equipment would reduce the negative association with mires ("sinking, drowning") to a level acceptable for general public. Compared to the fixed structures like boardwalks, such trails can be also more easily altered and less expensive, shifting for example because of the seasonal variation in landscape, as the 'alteration' is related to the visitor, not to the landscape. They cannot replace boardwalks entirely but would supplement existing trails for the more demanding visitor.

Other recreational activities in the mire include various sports (hiking, skiing, orienteering). These activities are not that common, but the attachment with the mire is far more varied than simple walking on wooden roads. Mires, as difficult terrain to pass and navigate, are challenging, and therefore good landscapes for physically demanding recreational activities like amateur sport.

Creative recreational activity such as photography is one of the emerging reasons to visit mires. Relatively open mires (specially raised bogs) are visually accessible and attractive as they are different from every-day landscapes. Already existing boardwalks and viewing towers offer a very good platform for photography. The latter is closely tied with other recreational activities: some people go 
to the mire to take photographs, other take photographs because they are in mire.

\section{Mire in the common perception}

The most common keywords associated with mires demonstrate dissimilarities with the directly formulated purposes and activities that draw people to the mires. For example, picking berries is one of the top reasons for going to the mire, but it is not so prominent among the given keywords. The most popular keywords arise from roughly two considerations: the attempt to define what mire is by specifying its most distinctive features, and the sensory and emotional experience of mires.

The most distinctive feature of the mire is related to excessive water and lack of solid ground. The kinesthetic experience of walking on the soft ground is fundamentally unsettling and is perhaps one of the sources of fright that dominates the common lore about mires. It is remarkable that in the age of boardwalk-dominated visits the kinesthetic sense is still so important in the popular definition of mire, although it is not a common experience anymore. Sinking or drowning in the mires is possible only in particular parts of the mires such as hollows or quagmires. Both microforms are easily recognizable but it seems that this knowledge is largely forgotten and frightening associations are spread over the entire mire landscape. The most commonly visited place, the raised bog is actually relatively safe to cross.

Quite remarkable references to plants and vegetation can be related to the distinctive visual characteristics of bogs, or also, to the school biology curriculum. The plant species mentioned are characteristic of raised bogs and easily visually recognizable (for instance different types of Sphagnum, Andromeda, Calluna vulgaris etc.) or have other specific characteristics that attract attention: for instance, Ledum palustre is recognizable because of its smell.

Plants that are more common in transitional bogs or in fens have been mentioned less often. This may be explained through the respondents' experiences - people have mostly visited bogs. Other references to landscape ecological information about mires (e.g. lack of nutrients, lack of diversity) were rare.

The predominance of the sensory and emotional associations in relation to the mire indicates the contemporary social construction of mires as (touristic) wilderness. In sociological theories, tourism has essentially been interpreted as an es- cape of the modern man from his standardized and alienating everyday/work environments and his search for authentic experience and mythical structures (MacCannell 1976; Urry 1990). These qualities have most often been projected upon historical and heritage sites, rural landscapes and pristine nature - "the peripheries of the modern world, where nature, wildernesses, and indigenous or other cultural groups untouched by modernity are situated" (Saarinen 2004: 438). Although tourist landscapes are largely symbolic creations representing the dreams of their consumers and are also consumed symbolically through the "tourist gaze" (Urry 1990, 1995), they also entail physical involvement with real physical surroundings and multisensory embodied experience is increasingly sought after in tourist encounters (see for example Markwell 2001; Franklin 2003).

All senses receive 'uncommon' input in mire and this overwhelming combination of unusual stimuli may be the reason for the distinctive liminal, 'different' perception of the mires. This natural property of mires has already been noticed by tourist operators and the potential of mires as a tourist attraction is very high.

Common perception of the mire today is mostly shaped by the role of the tourist/symbolic consumer vis-à-vis wild nature. The mire appears as a beautiful pristine place, peaceful and wild wet and soft ground. In its orientation to the aesthetic and emotional values of the landscape, the common perspective diverges from the technical definition in landscape ecology built upon quantifiable features (at least $30 \mathrm{~cm}$ thick peat-layer). However, these definitions are complementary as the cultural definition adds emotional descriptions to the distinctive soil properties - what the landscape looks like and how does it make people feel.

\section{Changes in the meaning of mires over the $20^{\text {th }}$ century}

This chapter presents changes in the perception of mires in Estonia in the context of major socio-economic shifts in the $20^{\text {th }}$ century and the corresponding paradigmatic shifts in the cultural perception of culture-nature relationships.

\section{Stage 1. Traditional: mire as liminal landscape}

In traditional perception, the mire lies semiotically at the utmost border of familiar and inhabited 
space representing thus an interface, a meeting ground with the "other side" (Pungas \& Võsu 2012). Such status was marked by the numerous warnings, prohibitions and rules of conduct reflected in the cultural heritage about mires (Hiiemäe 1988; Pungas \& Printsmann 2010) that evoked the feelings of uneasiness and fear, and consequently, a heightened awareness of one's surroundings while in the mire. On the other hand, in cases of acute threat the mire could temporarily be adopted as home. Also, during more peaceful times the symbolic status of mires did not prevent or prohibit people from taking advantage of the naturally available resources of bogs and mires. Traditional communities' relationship to the mire could thus be characterized as adaptable and pragmatic accommodating diverse ways of practical engagement within a defined set of communal values.

\section{Stage 2. Industrial: enculturing the mire}

Endeavors to transform the landscape into something more useful - cultivable land, if not suitable for harvesting food crops then at least forest or peat - mark a transition to modern mentality. The shift occurred gradually over time as the first systematic melioration projects in Estonia were documented in the $17^{\text {th }}$ century, but the process peaked only in the $20^{\text {th }}$ century. From the exclusively industrial point of view natural mires appeared unambiguously useless and thus automatically became subjects for alteration. The speed at which they were vanishing accelerated in accordance with the advancement of relevant technologies and only abated as the voices of environmentalists got more alarming.

Industrial mentality evaluated mires or the natural environment altogether first and foremost in terms of direct resources exploitable for human ends. The variegated traditional relations were thus at least officially replaced with a single-dimensional ideological perception. The tendency towards disambiguity is illustrated by the scientific pursuits to define mires upon a single measurable parameter, the thickness of peat-layer for example. The development of tools increased the physical as well as symbolic distance between man and natural environment with the relationship becoming increasingly virtual while immediate multisensory contact with the environment has been gradually replaced by indirect contact mediated by technology.
Stage 3. Ecological: aestheticization of mire

A second shift in the meaning of mires in Estonia can be dated to around 1970 when an influential naturalist Viktor Masing published a series of articles in a popular magazine Eesti Loodus (Estonian Nature) to eradicate prevalent negative prejudices about the mires and to present an alternative to the undisputed agenda of their melioration (Masing 1970a, 1970b, 1970c). Among other arguments he also referred to the recreational, aesthetic, scientific and ethical values of mires and argued that for these as well as for ecological reasons the remaining natural mires would best be left unspoiled.

His arguments echoed the more general process of redefining wilderness/nature in the post-industrializing West that was stemming from at least two sources. On the one hand, the symbolic desire for authentic existence projected upon the past and upon 'unspoiled' natural environment gave birth to tourism (as an economy as well as existential condition) (Wilson 1992). On the other hand, the perceptible loss of natural areas contributed to the quick advancement of ecological science and to the rise of ecological awareness more generally. Establishing of protected areas and natural parks has been seen as a practical solution to both of these concerns. However, the socio-cultural aspects of their creation have not been critically analyzed until quite recently (see for example Lindahl Elliot 2006; West et al. 2006). These analyses demonstrate that cultural perceptions about what can pass as genuine nature appear to be as important as ecological reasons in the creation of protected areas. In the establishment of "natural landscapes" semiotic and ecological processes are intertwined (Kull 1998).

The problem with the conservationist approach lies in its excluding some chosen areas from the human inhabitable realm and leading to nature becoming an enclave, spatially as well as symbolically (see Edensor 2001, 2009 for enclavic space). These natural enclaves then become attractions for tourism and true examples of 'nature' leaving the inhabited or managed environments out of the definition and depriving them from relevant concern. The result of the questionnaire reveals that the respondents know that almost $1 / 4$ of Estonian territory is covered by mires; however, they do not perceive that most of these are actually seriously altered. The gained experience and knowledge about the visited mires (almost exclusively raised bogs) are assumed to be true to all mires. The spa- 
tial extent of all mires (22\% of the Estonian territory) is remembered from school textbooks, which until very recently used to refer to the technical definition of the mire based on peat thickness. As a result, people overestimate the extent of the mires that they can remember from their personal experience from visits and visual media. The fact that nearly $2 / 3$ of former mires are now drained is not common knowledge.

Another problem lies in the contradiction inherent in tourism industry that both creates as well as destroys its destinations. The creation of tourist destinations is first and foremost symbolical (Knudsen et al. 2013) but often leads to physical developments, for instance the relevant infrastructure. These developments and the increasing flow of tourists, however, erode the very same qualities upon which the destination was established. For example, Leivits et al. (2009) show that a new boardwalk that caused a fivefold increase in the number of visits has had a clear negative impact on the breeding of rare birds in Nigula nature reserve. In the case of fragile natural communities and protected areas it is necessary to set some limits to tourism development. The initiatives of sustainable tourism or ecotourism have emerged as forms of self-regulation of the tourism industry to cope with this problem and to help to create a balance of tourist and preservation goals in protected areas.

\section{Practical solutions}

Because of the problems described above, a controversy appears between the purpose of establishing nature protection areas and the list of activities practiced there. As Kimmel (2009: 21) mentions: "According to the assessment of total economic value of the main ecosystem services provided by wetlands (De Groot et al. 2006) the amenity and recreation services have higher monetary value than provisional or regulatory services, whereas the highest average value is related to aesthetic information services". It is necessary to consider both - to protect rare, often very sensitive ecosystems from further human impact and maintain nature trails in order to offer possibilities for personal contacts with nature.

Visitors should be channeled mostly to partially drained mires as such areas lack the very 'prime' quality and therefore are not under protection, being also quite resilient to further modest continuous human impact such as boardwalks and visits because "the sensitive part" is already gone. At the same time, they offer the same emotional experiences as the 'prime' areas. The difference between them often lies in the size and diversity of the landscape complex, while the scale cannot be perceived during short-time visits, or in the presence of some rare, sensitive species, that are hard to recognize and even harder to spot at all. Such partially drained areas should be located in the buffer zones of protected mires as specific zones with a clearly stated educational purpose - allowing visitors to state "I visited this unique nature reserve", but preserving its most valuable parts from actual impact.

Educational nature trails should also present and describe mires altered by humans; for this purpose slightly damaged (drained, harvested for peat) mires can be used as these demonstrate direct human impact on the mire. The added option of demonstrating traditional practices like peat cutting, winter roads, etc. in such slightly damaged sites could provide extra value from the (cultural) heritage point of view. The traditional boardwalks should be accompanied with shifting bog shoe trails allowing profounder experiences/contact for a more demanding visitor.

In parallel, people's direct attachment with the surroundings would be enhanced. This makes slightly altered mire areas even more valuable than natural wild mires from the human point of view, and institutional aims will cover more precisely people cultural understanding of mire.

\section{Conclusions}

Perception of a landscape is inherently tied to and affecting its physical shape. The generally negative perception of mires as useless land has led to the fast disappearance of natural mires in Estonia over the $20^{\text {th }}$ century. The recognition of their ecological value as well as recreational potential near the turn of the $20^{\text {th }}$ and $21^{\text {st }}$ centuries has changed this general perception.

The most common activities that have taken people to the mires have considerably changed over the centuries, altering also the perception of and cultural attitudes towards the mire. Folkloric material shows that traditionally mires were feared and avoided as ambivalent places. They were only populated in disruptive times when seeking refuge from wars and plagues, although some pragmatic engagements like hunting, gathering, winter transport etc. would occasionally still take people to the mire. In the traditional frame of reference mires 
can be interpreted as liminal places at the borderline of the everyday cultural world and its outside.

While traditional practices had hardly any remarkable or long-term effects on mires, economic interests and melioration works that accompanied modernization processes over the 20th century totally transformed the whole mire landscape in Estonia. Mires were mostly drained for peat extraction and agricultural (forestry) purposes. Industrial mentality encultured mires were encultured physically as well as symbolically.

The third frame of reference, which we can term as ecological, started to emerge around the 1970s when the need to protect the remaining natural mires surfaced. Attributing value to the "peripheries of the modern world", tourism industry contributed to this attitude, exhibiting wild nature as a resource of aesthetic and emotional pleasure.

Gathering appears as a somewhat exceptional practice that has persisted through time accommodating to the shifting paradigms. Today it can be performed merely as a recreational practice or else as a practical engagement contributing to one's livelihood and intimate contact with the mire.

A study of 767 questionnaires revealed that the common associations with the mire today are mostly related to its aesthetic and emotional value based upon personal sensory experiences in the mire as tourists as well as upon its symbolic representations.

The common perception diverges from the landscape ecological perspective which approaches the mire from a quantitative, pragmatic viewpoint acknowledging its ecological value. The extent of natural mires is overestimated in common perception since it is based on experiences mainly gained from protected mires that actually form only a small proportion of all peat-lands. To align the popular image of and ecological information about mires and relieve tourist pressure on protected habitats it is suggested that more visitors be directed to partly drained mires. The manner in which nature tourism entrepreneurship combines embodied experience and traditional practices with educational aims in consumer contexts can contribute to new possibilities for more sustainable mire management in the future.

\section{ACKNOWLEDGEMENTS}

This article has been supported by the European Union through the European Regional Development
Fund (Center of Excellence in Cultural Theory, CECT); the Estonian Ministry of Education target-financed project IUT SF0180049s09; the institutional research funding projects IUT3-2, IUT2-44 and IUT2-16; and the Estonian Science Foundation (grant No. 8040). Ene-Reet Soovik is most gratefully appreciated for language revision.

\section{REFERENCES}

Bardone E \& Pungas-Kohv P 2015. Changing values of wild berries in Estonian households: recollections from an ethnographic archive. Journal of Baltic Studies. Accepted.

Cosgrove DE 2003. Landscape: ecology and semiosis. In Palang $\mathrm{H}$ \& Fry $\mathrm{G}$ (eds). Landscape interfaces: cultural heritage in changing landscapes, 15-21. Kluwer Academic Publishers, Dordrecht.

Costanza R, D’Arge R, De Groot R, Farber S, Grasso M, Hannon B, Limburg K, Naeem S, O'Neill R V, Paruelo J, Raskin RG, Sutton P \& van den Belt M 1997. The value of the world's ecosystem services and natural capital. Nature 387, 253-260. http://dx.doi.org/10.1038/387253a0.

De Groot R, Stuip M, Finlayson M \& Davidson N 2006. Valuing wetlands: guidance for valuing the benefits derived from wetland ecosystem services. Ramsar Technical Report 3/CBD Technical Series 27. Ramsar Convention Secretariat, Gland and Secretariat of the Convention on Biological Diversity, Montreal.

Eilart J 1986. Looduse õpperajad. Valgus, Tallinn.

Einer V 1980. Vanade soosildade jälgedel. Eesti Loodus 3, 188-189.

Einer $\mathrm{V}$ 1988. Korilasrajast kiirteeni. Valgus, Tallinn.

Edensor T 2001. Performing tourism, staging tourism: (re)producing tourist space \& practice. Tourist Studies 1, 59-82.

Edensor T 2009. Tourism and performance. In Jamal T \& Robinson M (eds). The SAGE Handbook of Tourism Studies, 543-557. SAGE Publications, London.

Flick U 1998. An introduction to qualitative research. SAGE Publications, London, Thousand Oaks and New Delhi.

Franklin A 2003. Tourism: an introduction. SAGE Publications, London, Thousand Oaks and New Delhi.

French RA 1964. The reclamation of swamp in prerevolutionary Russia. Transactions of the Institute of British Geographers 34, 175-188.

Giblett R 1996. Postmodern wetlands: culture, history, ecology. Edinburg University Press, Edinburgh.

Heidegger M 1971. Building dwelling thinking. Poetry, language, thought. Harper Colophon Books, New York.

Hiiemäe M 1988. Sood rahvapärimuses. In Valk U (ed). Eesti sood, 221-223. Valgus, Tallinn.

Howarth W 2001. Reading the wetlands. In Adams PC, Hoelscher S \& Till KE (eds). Textures of place. 
Exploring humanist geographies, 55-83. University of Minnesota Press, London and Minneapolis.

Huijbens EH \& Pálsson G 2009. The bog in our brain and bowels: social attitudes to the cartography of Icelandic wetlands. Environment and Planning D: Society and Space 27, 296-316.

http://dx.doi.org/10.1068/d9508.

Ilomets M, Kimmel K, Stén C-G \& Korhonen R 2007. Sood Eesti ja Lõuna-Soomes. NGO GEO Guide Baltoscandia, Tallinn.

Ingold T 2000. The perception of the environment: essays in livelihood, dwelling and skill. Routledge, Taylor \& Francis Group, London and New York.

Ingold T \& Kurttila T 2000. Perceiving the environment in Finnish Lapland. Body and society 6: 3-4, 183-196.

http://dx.doi.org/10.1177/1357034X00006003010.

Joandi J 1990. Taliteid Viljandimaa ja Pärnu vahel. Eesti Loodus 41: 4, 257-261.

Joosten H \& Clark D 2002. The wise use of mires and peat lands. <http://www.mirewiseuse.com/> 01.05.2014.

Kask I 1990. Miks Pärnusse otse ei saa? Eesti Loodus 41: 4, 254-256.

Keisteri T 1990. The study of change in cultural landscapes. Fennia 168: 1, 31-115.

Kimmel K 2009. Ecosystem services of Estonian wetlands. Dissertationes Geographicae Universitatis Tartuensis 38. Tartu University Press, Tartu.

Kimmel K, Kull A, Salm J-O \& Mander Ü 2010. The status, conservation and sustainable use of Estonian wetlands. Wetlands Ecology and Management 18: 4, 375-395.

http://dx.doi.org/10.1007/s11273-008-9129-z.

Knudsen DC, Metro-Roland M, Rickly-Boyd \& Jillian M 2013. Landscape studies and tourism research. In Howard P, Thompson I \& Waterton E (eds). The Routledge companion to landscape studies, 286295. Routledge, Taylor \& Francis Group, London and New York.

Kohv M \& Salm J-O 2012. Soode taastamisest Eestis. Eesti Loodus 4, 10-16.

Kriiska A 2004. Aegade alguses. 15 kirjutist kaugemast minevikust. Tallinna Raamatutrükikoda, Tallinn.

Kull K 1998. Semiotic ecology: different natures in the semiosphere. Sign Systems Studies 26, 344-371.

Lavi A 1998. Eesti vanadest sooteedest. Eesti Arheoloogia Ajakiri 2, 65-93.

Lehtinen AA 2000. Mires as mirrors. Peat-lands - hybrid landscapes of the North. Fennia 178: 1, 125137.

Lehtinen AA 2010. Politics of decoupling: breaks between indigenous and imported senses of the Nordic North. Journal of Cultural Geography 29: 1, 105-123.

Lehtinen AA 2011. From relations to dissociations inspatial thinking: Sámi 'geographs' and the promise of concentric geographies. Fennia 189: 2, 14- 30.

Leivits M, Leivits A, Klein A, Kuus A, Leibak E, Merivee M, Soppe A, Tammekänd I \& Tammekänd J 2009.
Effects of visitor disturbance to the Golden Plover (Pluvialis apricaria) habitat suitability in Nigula bog. Hirundo 22, 53-63.

Lindahl Elliot N 2006. Mediating nature. Routledge, London.

Lindström K, Palang H \& Kull K 2013. Semiotics of landscape. In Howard P, Thompson I \& Waterton E (eds). The Routledge companion to landscape studies, 97-107. Routledge, London and New York.

Läänelaid I \& Loosalu J 1978. Kaubandus ja unustatud taliteed. Perioodika, Tallinn.

MacCannell D 1976. The tourist: a new theory of the leisure class. Schocken Books, New York.

Macnaghten P \& Urry J 1998. Contested natures. SAGE, London, California and New Delhi.

Maran T \& Kull K 2014. Ecosemiotics: main principles and current development. Geografiska Annaler: Series B, Human Geography 96: 1, 1-10. http://dx.doi.org/10.1111/geob.12035.

Markwell K 2001. An intimate rendezvous with nature? Tourist Studies 1: 1, 39-57.

Masing V 1968. Rabadest, nende arengust ja uurimisest. Eesti Loodus 8, 451-458.

Masing V 1970a. Kas rabad on tõesti nii kohutavad? Eesti Loodus 7, 386-391.

Masing $\mathrm{V} 1970 b$. Mida teha rabadega? Eesti Loodus 8, 473-477.

Masing V 1970c. Mida teha rabadega? Eesti Loodus 9 , 515-520.

Nöth W 1998. Ecosemiotics. Sign Systems Studies 26, 332-343.

Nöth W \& Kull K 2001. Introduction: special issue on ecosemiotics and semiotics of nature. Sign Systems Studies 29.1, 9-11.

Paal J \& Leibak E 2011. Estonian mires: inventory of habitats. Regio, Tartu.

Paal T 2011. Metsamarjade ja seente varumine. In Kusmin T \& Meikar T (eds). Akadeemilise Metsaseltsi toimetised XXV. Metsa kõrvalkasutus Eestis, 67-72. Eesti Metsaselts, Tartu.

Paas M 2005. Laudtee - üks loodushoiu võimalustest. Diploma thesis, Räpina.

Printsmann A, Külvik M \& Alumäe H 2004. Miljonivaade Eestimaale. Eesti Loodus 10, 40-42.

Pungas P \& Printsmann A 2010. Soo rollid ja sookollid. In Kalmre E (ed). Tulnukad ja internetilapsed: uurimusi laste- ja noortekultuurist. Tänapäeva folkloorist 8, 257-280. Publishing House of Estonian Literary Museum, Tartu.

Pungas P \& Võsu E 2012. The dynamics of liminality in Estonian mires. In Andrews H \& Roberts L (eds). Liminal landscapes: travel, experience and spaces in-between, 87-102. Routledge, London and New York.

Reimann M, Lamp M-L \& Palang H 2011. Tourism impacts and local communities in Estonian national parks. Scandinavian Journal of Hospitality and Tourism 11: 1, 87-99.

http://dx.doi.org/10.1080/15022250.2011.638206.

Rähni B 2012. Personal communication. 
Saareste A 1958. Eesti keele mõistelise sõnaraamatu indeks. <http://www.eki.ee/cgi-bin/saareste. cgi?osa $=p \&$ sona $=$ so $>01.05 .2014$.

Saarinen J 2004. Tourism and touristic representations of nature. In Lew AA, Hall MC \& Williams AM (eds). A companion to tourism, 438-449. Blackwell Publishing, Blackwell.

State Forest Management Centre (SFMC) 2014. SFMC suggest - berries and mushrooms are ready. <http://www.rmk.ee/teemad/metsasoprade-klubi/uudiskirjad/juuli-2009/rmk-soovitab> 20.06.2014.

Tanskanen M 2011. The cultivated mire landscape as a mirror of Finnish society. In Roca Z, Claval P \& Agnew J (eds). Landscapes, identities and development: Europe and beyond, 195-206. Ashgate, Farnham.

Tooman H \& Ruukel A 2012. Sustainable development of a remote tourist destination. The case of Soomaa national park, Estonia. In Legrand W, Simons-Kaufman C \& Sloan P (eds). Sustainable hospitality and tourism as motors for development. Case studies from developing regions of the world, 276-295. Routledge, London and New York.

Tüür K \& Maran T 2005. Eesti looduskirjanduse lugu. In Maran T \& Tüür K (eds). Eesti Looduskultuur, 237-270. Eesti Kirjandusmuuseum, Tartu.
Tõnisson E 1972. Mida teame muistsetest pelgupaikadest? Eesti Loodus 3, 168-172.

Urry J 1990. The tourist gaze: leisure and travel in contemporary societies. Sage, London.

Urry J 1995. Consuming places. Routledge, London.

Valk U 1988. Eesti sood. Valgus, Tallinn.

Van de Noort R 2004. The Humber wetlands: the archaeology of a dynamic landscape. Windgather Press Ltd, Bollington and Macclesfield.

von Uexküll J 1982 [1940]. The theory of meaning. Semiotica 42: 1, 25-82.

von Uexküll J 1992 [1934]. A stroll through the worlds of animals and men: a picture book of invisible worlds. Semiotica 89: 4, 319-391.

West P, Igoe J \& Brockington D 2006. Parks and peoples: the social impact of protected areas. Annual Review of Anthropology 35, 251-277. http://dx.doi.org/10.1146/annurev.anthro.35.081705.123308.

Wilson A 1992. The culture of nature: North American landscape from Disney to the Exxon Valdez. Blackwell, Oxford.

Wylie J 2007. Landscape - key ideas in geography. Routledge, London. 